\title{
Glucocorticoid receptor expression in resident and hematopoietic cells in lgG4-related disease
}

\author{
Taku Iguchi $^{1,2} \cdot$ Koji Takaori $^{3,14} \cdot$ Akiko Mii $^{3,15}$ - Yuki Sato ${ }^{1,3} \cdot$ Yasunori Suzuki $^{4} \cdot$ Hajime Yoshifuji $^{5}$ - Hiroshi Seno ${ }^{6}$. \\ Osamu Ogawa ${ }^{7} \cdot$ Koichi Omori $^{8} \cdot$ Kazuhisa Bessho $^{9} \cdot$ Satoru Kondo $^{10} \cdot$ Tomokazu Yoshizaki $^{10} \cdot$ Hitoshi Nakashima $^{11}$. \\ Takao Saito $\mathbb{D}^{12} \cdot$ Tsuneyo Mimori $^{5} \cdot$ Hironori Haga ${ }^{13} \cdot$ Mitsuhiro Kawano $^{4} \cdot$ Motoko Yanagita $^{3}$
}

Received: 18 December 2017 / Revised: 17 January 2018 / Accepted: 17 January 2018 / Published online: 12 February 2018

(c) United States \& Canadian Academy of Pathology 2018

\begin{abstract}
Immunoglobulin G4-related disease is a rare immune-mediated disease characterized by the infiltration of IgG4-positive plasma cells and unique storiform fibrosis of multiple organs. The majority of IgG4-related disease patients respond to glucocorticoids, yet the precise mechanism of their action remains unclear. Pathological sections of the submaxillary gland, kidney, and retroperitoneum from 20 patients in total diagnosed with IgG4-related disease were analyzed for glucocorticoid receptor expression and the cell types expressing glucocorticoid receptor. Strong and abundant expression of glucocorticoid receptor was observed in the submaxillary gland, kidney, and retroperitoneum of IgG4-related disease patients, while glucocorticoid receptor was rarely or only faintly observed in the submaxillary gland of patients with Sjögren's syndrome, radicular cysts and sialolithiasis or in the healthy kidney. Glucocorticoid receptor was mainly expressed in fibro/ myofibroblasts, CD4-positive T cells and IgG4-positive plasma cells in the submandibular glands and kidneys of IgG4related disease patients. The abundant expression of glucocorticoid receptor in various types of cells, including resident fibro/myofibroblasts in IgG4-related disease patients might provide clues to the mechanism of steroid responsiveness in IgG4-related disease patients.
\end{abstract}

Electronic supplementary material The online version of this article (https://doi.org/10.1038/s41379-018-0036-4) contains supplementary material, which is available to authorized users.

Motoko Yanagita

motoy@kuhp.kyoto-u.ac.jp

1 TMK Project, Medical Innovation Center, Kyoto University Graduate School of Medicine, Kyoto, Kyoto, Japan

2 Research Unit/Innovative Medical Science, Sohyaku Innovative Research Division, Mitsubishi Tanabe Pharma Corporation, Toda, Saitama, Japan

3 Department of Nephrology, Kyoto University Graduate School of Medicine, Kyoto, Kyoto, Japan

4 Division of Rheumatology Department of Internal Medicine, Kanazawa University Graduate School of Medicine, Kanazawa, Ishikawa, Japan

5 Department of Rheumatology and Clinical Immunology, Kyoto University Graduate School of Medicine, Kyoto, Kyoto, Japan

6 Department of Gastroenterology and Hepatology, Kyoto University Graduate School of Medicine, Kyoto, Kyoto, Japan

7 Department of Urology, Kyoto University Graduate School of Medicine, Kyoto, Kyoto, Japan
8 Department of Otolaryngology-Head and Neck Surgery, Kyoto University Graduate School of Medicine, Kyoto, Kyoto, Japan

9 Department of Oral and Maxillofacial Surgery, Kyoto University Graduate School of Medicine, Kyoto, Kyoto, Japan

10 Department of Otolaryngology-Head and Neck Surgery, Kanazawa University Graduate School of Medicine, Kanazawa, Ishikawa, Japan

11 Division of Nephrology and Rheumatology, Department of Internal Medicine, Faculty of Medicine, Fukuoka University, Fukuoka, Fukuoka, Japan

12 Sanko Clinic, Fukuoka, Fukuoka, Japan

13 Department of Diagnostic Pathology, Kyoto University Hospital, Kyoto, Kyoto, Japan

14 Present address: Department of Nephrology, Japanese Red Cross Otsu Hospital, Otsu, Shiga, Japan

15 Present address: Divisions of Nephrology, Department of Internal Medicine, Nippon Medical School, Tokyo, Japan 


\section{Introduction}

Immunoglobulin G4-related disease (IgG4-related disease) is a newly recognized systemic disease characterized by a lymphoplasmacytic infiltrate rich in IgG4-positive plasma cells, storiform fibrosis, and elevated serum $\mathrm{IgG} 4$ concentration. Reflecting the attention recently focused on these unique pathological changes and clinical parameters, the number of case reports describing IgG4-related disease has increased in the past few years. IgG4-related disease affects a variety of organs, including the central nervous system, lacrimal glands, salivary glands, pancreas, periaorta/retroperitoneum, lymph nodes, and kidneys [1-3]. Its effect on the kidneys is referred to as IgG4-related kidney disease (IgG4-RKD). Tubulointerstitial nephritis associated with marked infiltration of IgG4-positive plasma cells and fibrosis is the most frequent manifestation in IgG4-RKD [4-7], and various glomerular lesions, including membranous nephropathy [8], and renal pelvic lesions are also observed.

While much remains unknown about the pathogenesis of IgG4-related disease, it is clearly recognized that the majority of patients have a rapid and good response to glucocortiocoids [1]. Glucocorticoids are generally used to treat patients with inflammatory, allergic, and immunological disorders. They exert their effects through the activation of glucocorticoid receptor, a member of the nuclear hormone receptor superfamily. Glucocorticoids pass through the plasma membrane and bind to glucocorticoid receptor in the cytoplasm. The glucocorticoid-glucocorticoid receptor complex then moves to the nucleus, where it binds to DNA sequences called glucocorticoid-responsive elements, through which glucocorticoid receptor-mediated trans-activation and transcription of gene expression are mediated [9].

While glucocorticoids are currently the first-line treatment for remission induction in IgG4-related disease [6, 10-13], their mechanism of action and the cell types that respond to them remain unclear. Some studies have analyzed the expression of glucocorticoid receptor in peripheral blood samples of patients with autoimmune diseases [14]. One report indicated lower glucocorticoid receptor numbers in the peripheral blood of female but not male rheumatoid arthritis patients [15]. Another report indicated lower glucocorticoid receptor expression in peripheral blood mononuclear cells from systemic lupus erythematosus patients and a negative correlation between glucocorticoid receptor expression and disease activity [16], though others have denied this correlation [17]. To our knowledge, however, no studies have previously analyzed the expression of glucocorticoid receptor in the affected tissues.

In this study, we clearly demonstrated that glucocorticoid receptor is abundantly expressed in the submandibular glands, kidneys and retroperitoneum in IgG4-related disease patients, though it is rarely observed in these tissues in patients with non-IgG4-related diseases, such as Sjögren's syndrome. Surprisingly, glucocorticoid receptor was expressed not only in lymphocytes but also in fibroblasts. Our results provide the basis for an improved understanding of the mechanism of glucocorticoid responsiveness in IgG4related disease.

\section{Materials and methods}

\section{Human tissue analysis}

We analyzed 41 cases in total. All human specimens were procured and analyzed after informed consent and with approval of the Ethics Committee of Kyoto and Kanazawa University Hospitals (Kyoto University: Study No. R300, Kanazawa University: Study No. 833). Experienced pathologists confirmed the diagnosis of IgG4-related disease and other diseases utilized as controls. The diagnosis of IgG4-related disease was made by experienced pathologists according to comprehensive diagnostic criteria [18]. We used paraffin-embedded sections of patients diagnosed with IgG4-related disease (submandibular gland; $n=10$, kidney; $n=7$, retroperitoneum; $n=3)$, Sjögren's syndrome $(n=$ $10)$, radicular cyst $(n=2)$, and sialolithiasis $(n=6)$ at Kanazawa and Kyoto University Hospitals. We also analyzed non-cancerous regions of kidneys resected due to renal cell carcinoma as controls $(n=3)$. Clinical information of individual patients was anonymized in a linkable way.

\section{Histological studies and immunostaining}

Tissues were fixed in 10\% neutral buffered formalin solution and embedded in paraffin for hematoxylin and eosin (HE) staining and immunostaining. For immunostaining, tissue sections were deparaffinized, rehydrated, and treated with heat-induced epitope retrieval with $10 \mathrm{mM}$ sodium citrate $\mathrm{pH} 6$ in a microwave for immunohistochemistry or an autoclave for immunofluorescence, except for antiCD138 staining. For anti-CD138 staining, we performed heat-induced epitope retrieval with target retrieval solution pH 9 (\#S2367, Dako, CA, USA).

Primary antibodies against the following proteins were used for immunostaining: glucocorticoid receptor (\#12041, Cell Signaling Technology, Inc., MA, USA), CD45 (\#149457, eBioscience, CA, USA), CD4 (\#413181, Nichirei Bioscience Inc., Tokyo, Japan), CD8 (\#413201, Nichirei Bioscience), CD20 (\#14-0202, eBioscience), CD138 (\#ab34164, Abcam, MA, USA), CD248 (\#MAB2626, EMD Millipore, MA, USA), and pan-cytokeratin (\#C2562, Sigma-Aldrich, MO, USA). FITC-conjugated anti-IgG4 antibody (\#AF009, Binding Site Ltd., Birmingham, UK) 
Table 1 Clinical features of 10 patients with IgG4-related sialadenitis

\begin{tabular}{|c|c|c|c|c|c|c|c|c|c|c|}
\hline No. & Age/sex & $\begin{array}{l}\mathrm{IgG} \\
(\mathrm{mg} / \\
\mathrm{dL})\end{array}$ & $\begin{array}{l}\mathrm{IgG} 4 \\
(\mathrm{mg} / \\
\mathrm{dL})\end{array}$ & IgG4/IgG & $\begin{array}{l}\text { IgE } \\
\text { (IU/ } \\
\text { mL) }\end{array}$ & $\begin{array}{l}\text { CH50 } \\
\text { (U/mL) }\end{array}$ & $\begin{array}{l}\mathrm{C} 3 \\
(\mathrm{mg} / \\
\mathrm{dL})\end{array}$ & $\begin{array}{l}\mathrm{C} 4 \\
(\mathrm{mg} / \\
\mathrm{dL})\end{array}$ & $\begin{array}{l}\text { Extra } \\
\text { submandibular } \\
\text { affected organs }\end{array}$ & Diagnosis \\
\hline G1 & $74 / \mathrm{M}$ & 2938 & 1520 & 0.52 & 48 & 50 & 87 & 27 & LG, Ki, AA, Th & Definite \\
\hline G2 & 44/M & 1950 & 711 & 0.36 & 737 & 43 & 81 & 15 & LG, Lu, Ki & Definite \\
\hline G3 & $72 / \mathrm{M}$ & 1737 & 220 & 0.13 & 635 & 47 & 75 & 18 & PG, Lu & Definite \\
\hline G4 & $70 / \mathrm{F}$ & 1520 & 316 & 0.21 & 2701 & 57 & 96 & 27 & LG, PG, Pa, BD & Definite \\
\hline G5 & $47 / F$ & 2283 & 1360 & 0.60 & 794 & 42 & 71 & 15 & LG, Sk & Definite \\
\hline G6 & 73/M & 2936 & 1070 & 0.36 & 17 & 24 & 41 & 8 & LG, PG, Pa, Ki & Definite \\
\hline G7 & $72 / \mathrm{M}$ & 1936 & 361 & 0.19 & 8 & 10 & 56 & 3 & $\mathrm{Ki}, \mathrm{LN}$ & Definite \\
\hline G8 & $57 / \mathrm{F}$ & 1920 & 918 & 0.48 & 110 & 50 & 80 & 40 & $\mathrm{LG}, \mathrm{Lu}, \mathrm{Br}$ & Definite \\
\hline G9 & $75 / \mathrm{M}$ & 3506 & 1160 & 0.33 & 2328 & 39 & 59 & 8 & $\mathrm{Lu}, \mathrm{Pa}, \mathrm{AA}, \mathrm{Pl}$ & Definite \\
\hline G10 & $67 / F$ & 5531 & 2930 & 0.53 & 344 & 41 & 73 & 22 & LN & Definite \\
\hline
\end{tabular}

IgG serum IgG, IgG4 serum IgG4, IgE serum IgE, $C H 50$ serum $50 \%$ hemolytic unit of complement, $C 3$ serum complement component 3 , $C 4$ serum complement component 4, $L G$ lacrimal gland, $K i$ kidney, $A A$ abdominal aorta, $T h$ around thoracic vertebra, $L u$ lung, $P G$ parotid gland, $P a$ pancreas, $B D$ bile duct, $S k$ skin, $L N$ Lymph node, $B r$ Bronchus, $P l$ pleura

Table 2 Clinical features of 10 patients with Sjögren's syndrome sialadenitis

\begin{tabular}{|c|c|c|c|c|c|c|c|}
\hline No. & Age/sex & $\begin{array}{l}\text { ANA } \\
\text { (ratio) }\end{array}$ & $\begin{array}{l}\text { Anti-SSA } \\
\text { (index) }\end{array}$ & $\begin{array}{l}\text { Anti-SSB } \\
\text { (index) }\end{array}$ & $\begin{array}{l}\text { Rheumatoid factor } \\
(\mathrm{mg} / \mathrm{dL})\end{array}$ & $\begin{array}{l}\text { Focus } \\
\text { score }\end{array}$ & $\begin{array}{l}\mathrm{IgG}(\mathrm{mg} / \\
\mathrm{dL})\end{array}$ \\
\hline S1 & $55 / \mathrm{F}$ & $\times 320$ & 107.2 & 74 & $<10$ & 3.1 & 1750 \\
\hline $\mathrm{S} 2$ & $78 / \mathrm{F}$ & $\times 1280$ & 135.6 & 153 & 211 & 12.0 & 3630 \\
\hline S3 & $58 / \mathrm{M}$ & $<20$ & 114.3 & 20 & 129 & 2.3 & 1940 \\
\hline S4 & $82 / \mathrm{F}$ & $\times 80$ & 119.0 & 77 & NT & 12.0 & 1748 \\
\hline S5 & $41 / F$ & $\times 80$ & 132.6 & $<15$ & $<10$ & 1.7 & 2030 \\
\hline S6 & $53 / \mathrm{F}$ & $\times 640$ & 125.7 & 174 & NT & 3.5 & 3905 \\
\hline S7 & $72 / \mathrm{F}$ & $\times 320$ & 140.0 & $<15$ & 857 & 3.6 & 3300 \\
\hline S8 & $65 / F$ & $\times 80$ & 124.2 & $<15$ & 15 & 2.1 & 2150 \\
\hline S9 & $49 / \mathrm{F}$ & $\times 320$ & 111.6 & $<15$ & 31 & 3.3 & 3032 \\
\hline S10 & $74 / \mathrm{F}$ & $\times 320$ & 80.8 & $<15$ & 31 & 1.8 & 2690 \\
\hline
\end{tabular}

ANA serum anti-nuclear antibodies, anti-SSA serum anti-SSA/Ro antibodies, anti-SSB serum anti-SSB/La antibodies, IgG serum IgG

was utilized to visualize the IgG4-producing cells, and Cy3conjugated anti- $\alpha$-smooth muscle actin ( $\alpha$-SMA) antibody (\#C6198, Sigma-Aldrich) was utilized to visualize myofibroblasts.

For immunohistochemistry, the detection of primary antibodies was performed using IgG-HRP linked secondary antibody (\#NA934, GE Healthcare, WI, USA) in submandibular and salivary glands, and N-Histofine Simple Stain MAX PO (Nichirei Bioscience) in other tissues.

Immunohistochemistry samples were analyzed with Allin-One Fluorescence Microscope (BZ-X710; Keyence, Osaka, Japan), whereas immunofluorescence samples were analyzed with a confocal microscope (FV1000D; Olympus, Tokyo, Japan).

\section{Quantitative assessment of glucocorticoid receptor staining}

The prevalence and intensity of glucocorticoid receptor staining was scored semi-quantitatively by a pathologist blinded to the patients' clinical information. Each patient's score was determined to be negative (score 0), weakly positive (score 1), moderately positive (score 2), or strongly positive (score 3 ) based on the intensity of the staining and the prevalence of positive cells as previously described (Supplementary figure 1) [19].

Cell types of glucocorticoid receptor-expressing cells were assessed by co-staining of glucocorticoid receptor and cell markers. Four to fourteen fields at $\times 400$ magnification were analyzed in each specimen at the same laser 
Fig. 1 Expression of glucocorticoid receptor in the salivary and submandibular glands of patients with IgG4related disease and Sjögren's syndrome. a Massive lymphocyte infiltration in the labial salivary glands of patients with Sjögren's syndrome (left panel) and the submandibular glands of patients with IgG4related disease (right panel). b Glucocorticoid receptor was rarely or very sparsely expressed in the salivary glands in Sjögren's syndrome. The areas in the dotted squares of the upper panels are shown at higher magnification in the lower panels. c Glucocorticoid receptor was abundantly and intensely expressed in the submandibular glands of IgG4related disease. $\mathbf{d}$ The scoring of glucocorticoid receptor staining revealed that glucocorticoid receptor was more abundant in the patients with IgG4-related disease. Scale bars: $20 \mu \mathrm{m}$. Abbreviations: Sjögren's s, Sjögren's syndrome; IgG4-RD, IgG4-related disease; GR, glucocorticoid receptor
A
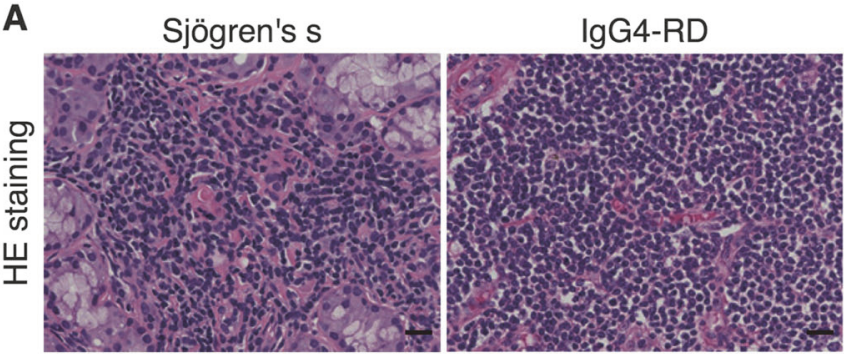

B Sjögren's s

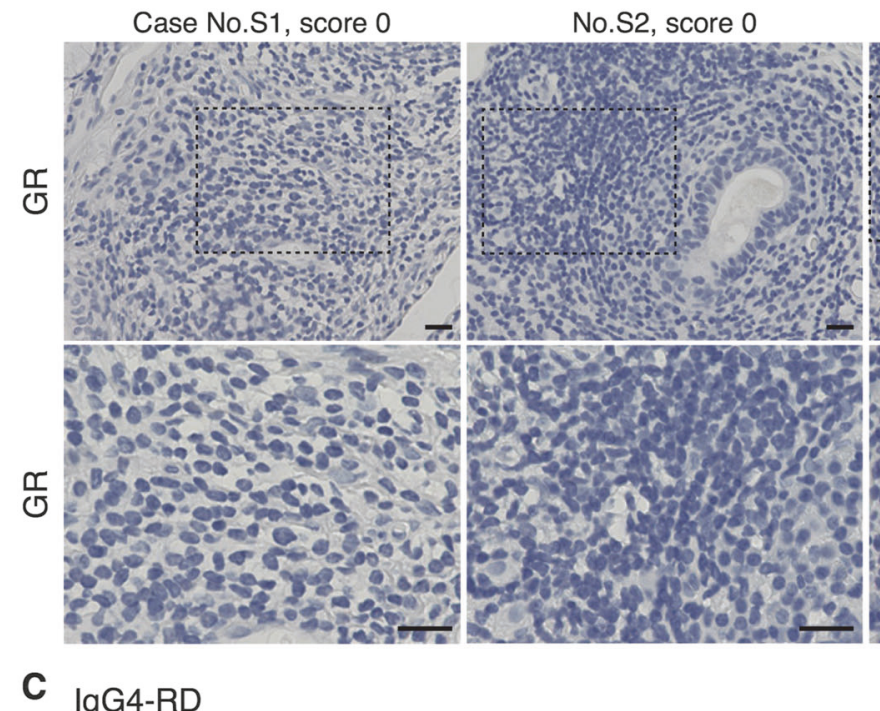

No.S2, score 0
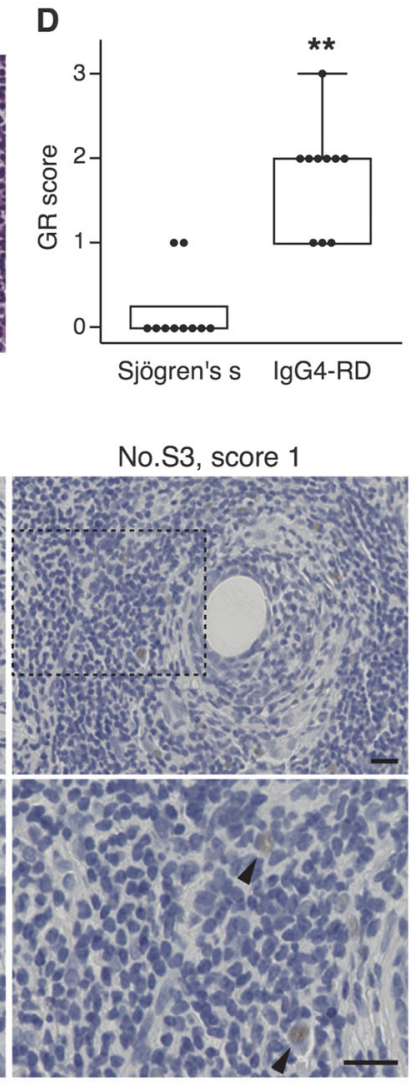

Sjögren's s IgG4-RD

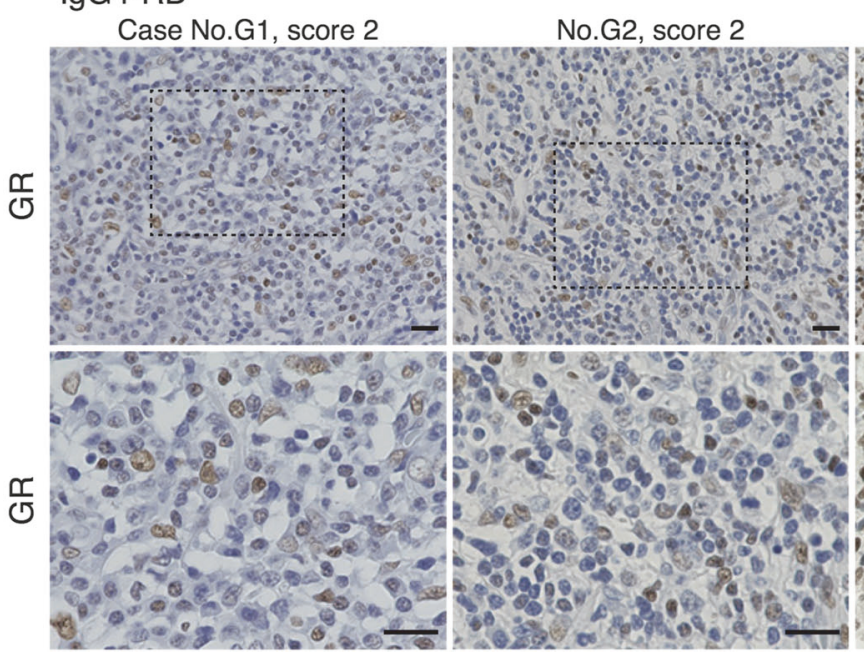

No.G3, score 3

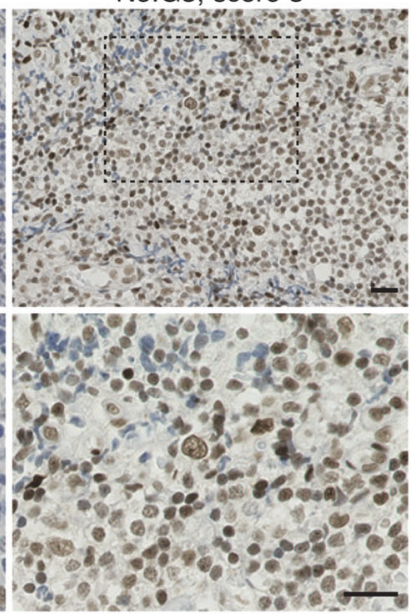

power and gain intensity with a confocal microscope (FV1000D; Olympus, Tokyo, Japan). The number of fields analyzed varied depending on the prevalence of the respective markers. The numbers of double- and singlepositive cells were automatically analyzed by Multi Wavelength Cell Scoring application supplied with MetaMorph software (Molecular Devices, CA, USA). Because co-staining with different markers was performed in different sections, the sum of these percentages could exceed $100 \%$.

\section{Statistics}

Data are shown as mean \pm SD. Statistical analysis was carried out using the statistical program EXSUS (ver. 8.1, CAC Croit Corporation, Tokyo, Japan). Differences 
Table 3 Clinical features of seven patients with IgG4-related kidney disease

\begin{tabular}{|c|c|c|c|c|c|c|c|c|c|c|c|c|c|}
\hline No. & Age/sex & $\begin{array}{l}\mathrm{IgG} \\
(\mathrm{mg} / \\
\mathrm{dL})\end{array}$ & $\begin{array}{l}\text { IgG4 } \\
(\mathrm{mg} / \\
\mathrm{dL})\end{array}$ & IgG4/IgG & $\begin{array}{l}\mathrm{IgE} \\
\text { (IU/ } \\
\mathrm{mL})\end{array}$ & $\begin{array}{l}\text { CH50 } \\
(\mathrm{U} / \mathrm{mL})\end{array}$ & $\begin{array}{l}\mathrm{C} 3 \\
(\mathrm{mg} / \\
\mathrm{dL})\end{array}$ & $\begin{array}{l}\mathrm{C} 4 \\
(\mathrm{mg} / \\
\mathrm{dL})\end{array}$ & $\begin{array}{l}\mathrm{Cr} \\
(\mathrm{mg} / \\
\mathrm{dL})\end{array}$ & $\begin{array}{l}\text { eGFR } \\
(\mathrm{mL} / \mathrm{min} / \\
\left.173 \mathrm{~m}^{2}\right)\end{array}$ & $\begin{array}{l}\text { urinary } \\
\text { protein } \\
(\mathrm{mg} / \mathrm{gCr})\end{array}$ & $\begin{array}{l}\text { Extrarenal } \\
\text { affected organs }\end{array}$ & Diagnosis \\
\hline K1 & $63 / \mathrm{M}$ & 1906 & 514 & 0.27 & 696 & 49 & 102 & 19 & 1.07 & 54.9 & 147 & SG, Ao, Pa & Definite \\
\hline K2 & $81 / \mathrm{M}$ & 3316 & 548 & 0.17 & 1053 & 6 & 37 & 1 & 1.57 & 33.6 & 3568 & $\begin{array}{l}\text { SG, Ao, Lu, } \\
\text { Th, LN, Pr }\end{array}$ & Definite \\
\hline K3 & $68 / \mathrm{M}$ & 3830 & 736 & 0.19 & 242 & 3 & 33 & 1 & 1.65 & 33.4 & 24 & $\mathrm{LN}$ & Definite \\
\hline K4 & $60 / \mathrm{M}$ & 1952 & 886 & 0.45 & 575 & 56 & 86 & 21 & 1.59 & 36.1 & 493 & LG, SG & Definite \\
\hline K5 & $81 / \mathrm{F}$ & 2022 & 143 & 0.07 & 1085 & 0 & 33 & 1 & 0.79 & 52.6 & 408 & $\mathrm{SG}, \mathrm{Lu}, \mathrm{LN}$ & Definite \\
\hline K6 & $64 / \mathrm{M}$ & 2128 & 880 & 0.41 & 171 & 52 & 89 & 17 & 0.92 & 76.8 & NT & SG, RP & Definite \\
\hline K7 & $60 / \mathrm{M}$ & 3530 & 600 & 0.17 & 440 & 21 & 53 & 6 & 0.91 & 66.4 & 50 & $\begin{array}{l}\text { LG, SG, Pa, } \\
\text { Ao }\end{array}$ & Definite \\
\hline
\end{tabular}

IgG serum IgG, IgG4 serum IgG4, IgE serum IgE, CH50 serum 50\% hemolytic unit of complement, $C 3$ serum complement component $3, C 4$ serum complement component $4, C r$ serum creatinine, $e G F R$ estimated glomerular filtration rate, $S G$ submandibular gland, $A o$ aorta, $P a$ pancreas, $L u$ lung, $T h$ around thoracic vertebra, $L N$ Lymph node, $\operatorname{Pr}$ prostate, $L G$ lacrimal gland, $R P$ retroperitoneum

NT: not tested due to the result of qualitative urinary test

between two groups were compared with Wilcoxon ranksum test. $P$-values $<0.05$ were considered significant.

\section{Results}

\section{Glucocorticoid receptor is abundantly expressed in the submandibular gland, kidney and retroperitoneum in IgG4-related disease}

To analyze the cell types responding to glucocorticoid in IgG4-related disease, we examined the expression of glucocorticoid receptor in various tissues of patients with $\mathrm{IgG} 4-$ related disease. First, we focused on IgG4-related sialadenitis (Table 1). Labial salivary gland inflammation in Sjögren's syndrome was utilized as a control (Table 2). While both tissues exhibited significant lymphocyte infiltration (Fig. 1a), glucocorticoid receptor was abundantly expressed in the submandibular glands of IgG4-related disease patients only (Fig. 1c), whereas it was undetectable or faintly observed in the salivary glands of Sjögren's syndrome patients (Fig. 1b). Semi-quantification of glucocorticoid receptor staining also revealed that glucocorticoid receptor expression was more abundant in the submandibular glands of IgG4-related disease patients (Fig. 1d). Glucocorticoid receptor expression was also faint in the salivary and submandibular glands of patients with other non-IgG4-related diseases, such as radicular cyst or sialolithiasis (Supplementary Figure 2).

We next examined the expression of glucocorticoid receptor in the kidney (Table 3) and found that glucocorticoid receptor was abundantly expressed in the tubular epithelial cells and the interstitial cells in the kidneys of IgG4-related disease patients (Fig. 2b), whereas its expression was sparse and faint in control kidneys (Fig. 2a). Glucocorticoid receptor expression was also detected in glomeruli of IgG4-related disease patients (data not shown) as previously reported in rapidly progressive glomerulonephritis glomerulus [20].

Glucocorticoid receptor was also expressed in the retroperitoneum of two IgG4-related disease patients who were reported to show retroperitoneum involvement, but not in one other patient (Fig. 3 and Table 4).

\section{Glucocorticoid receptor is expressed both in leukocytes and fibroblasts in the submandibular gland of IgG4-related disease patients}

Next, we analyzed the cell types expressing glucocorticoid receptor in the submandibular glands of IgG4-related disease patients, with particular attention to whether glucocorticoid receptor is expressed predominantly in inflammatory cells or in resident cells as well. The expression of glucocorticoid receptor was confirmed both in $\mathrm{CD}^{4} 5^{+}$leukocytes (Fig. 4a) and in fibroblasts (Fig. 4b), but was rare in epithelial cells (Fig. 4c). We quantified the ratio of glucocorticoid receptor expression in the submandibular glands of four patients (Table 1, case No. G3, G5, G9, and G10), and showed that the glucocorticoid receptorexpressing cells consisted of leukocytes and fibroblasts (Fig. 4d), whereas the percentage of glucocorticoid receptor-expressing leukocytes (or fibroblasts) in total leukocytes (or fibroblasts) were around 20\% (Fig. 4d).

Glucocorticoid receptor expression was found in $\mathrm{CD} 4{ }^{+}$ $\mathrm{T}$ cells (Fig. 4e), regulatory T cells (Tregs) (Fig. 4g), plasma cells (Fig. 4i), and $\mathrm{IgG}^{+}$cells (Fig. 4 j), but not in $\mathrm{CD}^{+}$ T cells (Fig. 4f) or CD20 ${ }^{+}$B cells (Fig. 4h). Glucocorticoid receptor was also expressed in $\alpha \mathrm{SMA}^{+}$myofibroblasts 
Fig. 2 Expression of glucocorticoid receptor in the healthy kidneys and the kidneys with IgG4-related disease. a In the control kidneys, the expression of glucocorticoid receptor was sparsely and faintly observed mainly in the interstitium. b In the kidney of IgG4-related disease, abundant and intense expressions of glucocorticoid receptor were observed both in epithelial cells and in the interstitium. Scale bars: $20 \mu \mathrm{m}$. Abbreviation: GR, glucocorticoid receptor
Fig. 3 Expression of glucocorticoid receptor in the retroperitoneum of IgG4-related disease patients. Glucocorticoid receptor was abundantly and strongly expressed in the retroperitoneum of case No. R1 and sparsely expressed in Case No. R2, but not in case No. R3 Scale bars: $20 \mu \mathrm{m}$. Abbreviation: GR, glucocorticoid receptor

\section{A Control (non-cancerous part of nephrectomy)}

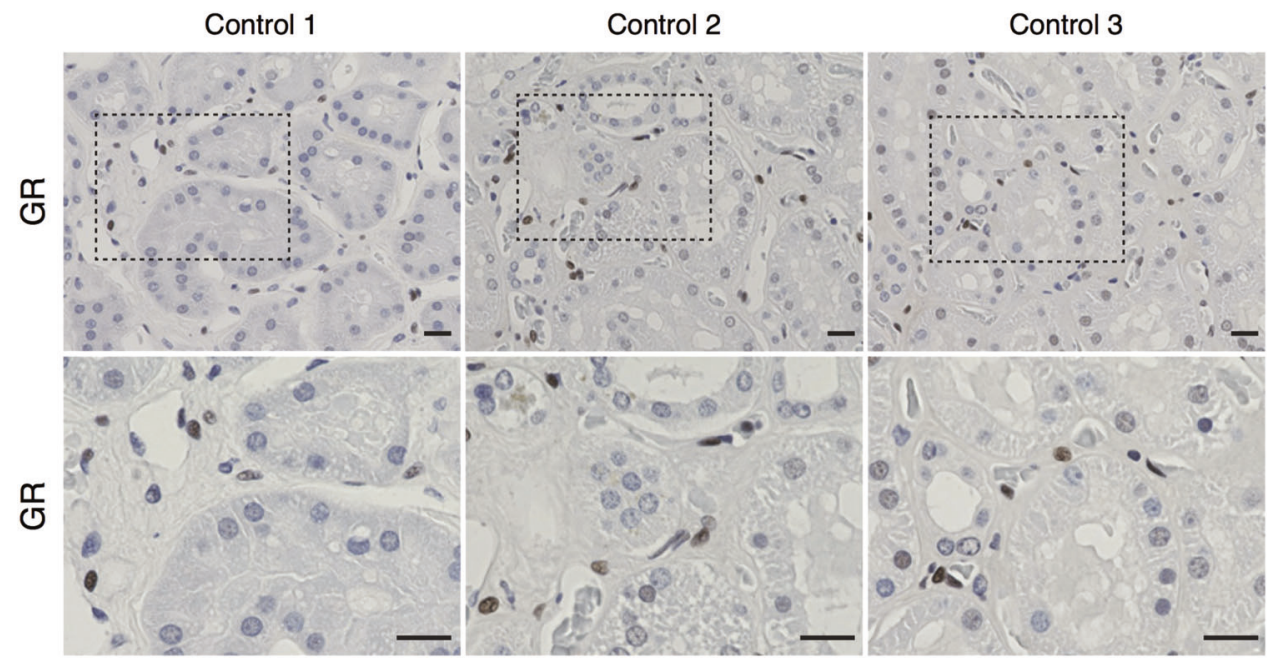

\section{B IgG4-RD (renal biopsy)}

Case No.K1

No.K2

No.K3

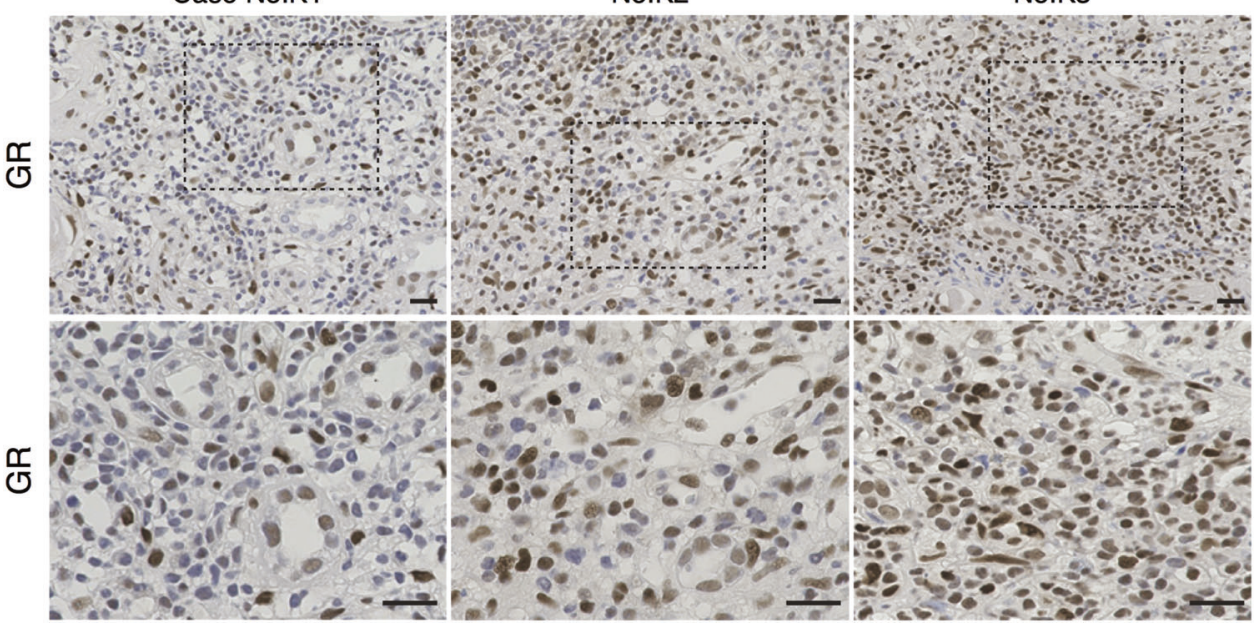

IgG4 related retroperitoneal fibrosis

\section{Retroperitoneum}

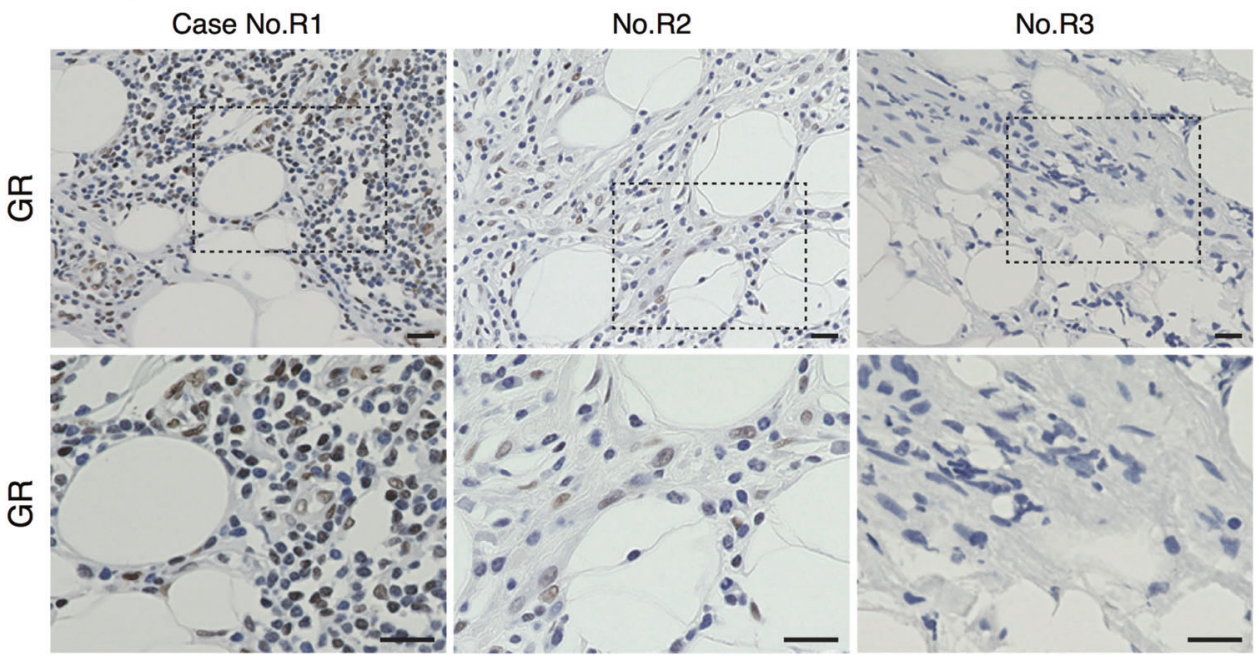


(Fig. 4k). The percentages of each cell type in glucocorticoid receptor-expressing cells were $50 \%$ in $\mathrm{CD}^{+} \mathrm{T}$ cells, $11 \%$ in regulatory $\mathrm{T}$ cells, $22 \%$ in plasma cells, $11 \%$ in $\mathrm{IgG} 4{ }^{+}$cells, and $36 \%$ in myofibroblasts in sections sampled from case No. G3 (Fig. 41). Furthermore, $42 \%$ of IgG4 ${ }^{+}$ cells expressed glucocorticoid receptor (Fig. 4l).

\section{Glucocorticoid receptor is expressed in $\mathrm{CD}^{+} \mathrm{T}$ cells, plasma cells, and fibroblasts in the kidney of IgG4- related disease patients}

We also examined the cell types expressing glucocorticoid receptor in the kidney of IgG4-related disease patients. Similar to the findings with submandibular glands, glucocorticoid receptor was expressed in both leukocytes (Fig. 5a) and fibroblasts (Fig. 5b). Glucocorticoid receptorexpressing cells were almost equally distributed in both leukocytes and fibroblasts (Fig. 5c) as calculated from four patients' data (Supplementary Table 3, cases No. K2, K5, $\mathrm{K} 6$, and K7).

Glucocorticoid receptor expression was found in $\mathrm{CD}^{+}$ $\mathrm{T}$ cells (Fig. 5d), plasma cells (Fig. $5 \mathrm{f}$ ), and $\mathrm{IgG}^{+}$cells (Fig. 5g) but not CD20 ${ }^{+}$B cells (Fig. 5e). Glucocorticoid receptor was also detected in $\alpha \mathrm{SMA}^{+}$myofibroblasts (Fig. 5h). The percentages of each cell type in glucocorticoid receptor-expressing cells in the kidney were $42 \%$ in $\mathrm{CD}^{+}{ }^{+}$cells, $54 \%$ in plasma cells, $14 \%$ in $\mathrm{IgG}^{+}$cells and $37 \%$ in myofibroblasts in sections sampled from Case No. K2 (Fig. 5i).

\section{Discussion}

In this study, we demonstrated that glucocorticoid receptor is abundantly expressed in the submandibular glands, kidneys, and retroperitoneum in IgG4-related disease patients, but not in patients with non-IgG4-related diseases, such as Sjögren's syndrome, radicular cyst and sialolithiasis, for which glucocorticoids are not effective. Although the precise mechanism of glucocorticoids' effectiveness for IgG4related disease remains unclear, a detailed study of glucocorticoid receptor expression in affected tissues might shed light on the matter.

There are some reports analyzing glucocorticoid receptor expression in peripheral blood mononuclear cells of patients with systemic lupus erythematosus. While there are conflicting data regarding the correlation between glucocorticoid receptor expression and disease activity [16, 17], one group has reported a positive correlation between glucocorticoid receptor expression in peripheral blood cells and the improvement of urinary protein and disease activity after glucocorticoid treatment, and concluded that glucocorticoid receptor expression in peripheral blood cells might predict responsiveness to glucocorticoid treatment [21]. To our knowledge, however, no studies have previously analyzed the expression of glucocorticoid receptor in the affected tissues of autoimmune diseases.

Glucocorticoid treatment is generally indicated for patients with inflammatory, allergic, and immunological disorders. Its therapeutic target is considered to be inflammatory cells which played a central role in the pathogenesis. For IgG4-related disease, because of the elevated serum $\mathrm{IgG} 4$ levels and abundant infiltration of $\mathrm{IgG} 4^{+}$plasma cells in affected tissues, it is widely assumed that B lymphocytes and plasma cells predominantly contribute to the pathogenesis of IgG4-related disease. On the other hand, some groups recently reported high-expression levels of type 2 helper T-cell cytokines (e.g., IL-4 and IL-13) and Treg cytokines (e.g., TGF- $\beta$ and IL-10) in the labial salivary glands [22], pancreas, bile ducts [23], and kidneys [24] of IgG4-related disease patients. IL-4 and IL-10 are regarded as the main triggers of IgG4 class switching, while IL-13 and TGF- $\beta$ are thought to promote extracellular matrix deposition by activating the trans-differentiation of fibroblasts to myofibroblasts $[3,25]$. In addition, the expression of IL-21, produced by follicular helper T cells, correlates with the number of ectopic germinal centers in the lacrymal and salivary glands of IgG4-related disease patients [26]. These findings indicated a possible contribution of type 2 helper $\mathrm{T}$ cell, Tregs and follicular helper $\mathrm{T}$ cells to the IgG4related disease pathogenesis as well. Our results showed that glucocorticoid receptor-expressing $\mathrm{CD} 45^{+}$cells are mostly $\mathrm{CD}^{+} \mathrm{T}$ cells and $\mathrm{CD} 138^{+}$plasma cells, but not $\mathrm{CD} 20^{+} \mathrm{B}$ cells. These results indicate that plasma cells acquire glucocorticoid receptor expression during their differentiation from $\mathrm{B}$ cells and, together with $\mathrm{CD} 4^{+}$ $\mathrm{T}$ cells, might respond directly to glucocorticoids. Of note, a considerable portion of $\mathrm{IgG}^{+}$cells expressed glucocorticoid receptor ( $42 \%$ in the submandibular glands in Fig. 41 and $27 \%$ in the kidney in Fig. 5i).

Furthermore, glucocorticoid receptor is also abundantly expressed in fibro/myofibroblasts. While glucocorticoid receptor expression was weak and sparse in the interstitium of healthy kidneys, glucocorticoid receptor expression was intense and abundant in the fibro/myofibroblasts of the submandibular glands and kidneys of IgG4-related disease patients, regardless of the presence or absence of storiform fibrosis. This result might indicate the phenotypic transition of fibroblasts in IgG4-related disease before the initiation of storiform fibrosis, a characteristic feature of IgG4-related disease [27].

Previously, we reported that resident fibroblasts transdifferentiate into myofibroblasts and predominantly contribute to renal fibrosis with concomitant loss-of-erythropoietin production using rodent models [28]. Additionally, we and others [29] demonstrated that dexamethasone administration restores 
Table 4 Clinical features of three patients with IgG4-related retroperitoneal fibrosis

\begin{tabular}{|c|c|c|c|c|c|c|c|c|c|c|c|c|}
\hline No. & Age/sex & $\begin{array}{l}\mathrm{IgG} \\
(\mathrm{mg} / \\
\mathrm{dL})\end{array}$ & $\begin{array}{l}\mathrm{IgG} 4 \\
(\mathrm{mg} / \mathrm{dL})\end{array}$ & $\mathrm{IgG} 4 / \mathrm{IgG}$ & $\begin{array}{l}\mathrm{IgE} \\
(\mathrm{IU} / \\
\mathrm{mL})\end{array}$ & $\begin{array}{l}\text { CH50 (U/ } \\
\mathrm{mL})\end{array}$ & $\begin{array}{l}\mathrm{C} 3 \\
(\mathrm{mg} / \\
\mathrm{dL})\end{array}$ & $\begin{array}{l}\mathrm{C} 4 \\
(\mathrm{mg} / \\
\mathrm{dL})\end{array}$ & $\begin{array}{l}\mathrm{Cr} \\
(\mathrm{mg} / \\
\mathrm{dL})\end{array}$ & $\begin{array}{l}\mathrm{eGFR}(\mathrm{mL} / \\
\mathrm{min} / 173 \\
\left.\mathrm{~m}^{2}\right)\end{array}$ & $\begin{array}{l}\text { Extra-retroperitoneal } \\
\text { affected organs }\end{array}$ & Diagnosis \\
\hline R1 & $66 / \mathrm{M}$ & 2324 & 518 & 0.22 & ND & 48 & 95 & 27 & 1.1 & 52.5 & $\mathrm{~Pa}, \mathrm{BD}, \mathrm{Ty}$ & Definite \\
\hline $\mathrm{R} 2$ & $68 / \mathrm{M}$ & 2791 & 540 & 0.19 & 174 & 38 & 90 & 21 & 0.8 & 73.8 & LG, SG, Pa, BD & Definite \\
\hline R3 & $76 / \mathrm{M}$ & 1527 & 458 & 0.30 & 440 & 50 & 101 & 22 & 0.9 & 73.1 & $\mathrm{~Pa}$ & Definite \\
\hline
\end{tabular}

$\operatorname{Ig} G$ serum $\operatorname{IgG}, \operatorname{Ig} G 4$ serum $\operatorname{IgG} 4, \operatorname{IgE}$ serum $\operatorname{IgE}, \operatorname{IgA}$ serum $\operatorname{IgA}$, $\operatorname{Ig} M$ serum $\operatorname{IgM}, C H 50$ serum $50 \%$ hemolytic unit of complement, $C 3$ serum complement component 3, $C 4$ serum complement component 4, $C r$ serum creatinine, $e G F R$ estimated glomerular filtration rate, $P a$ pancreas, $B D$ bile duct, $T y$ thyroid, $L G$ lacrimal gland, $S G$ submandibular gland

ND: no data

\section{Submandibular gland of IgG4-RD}
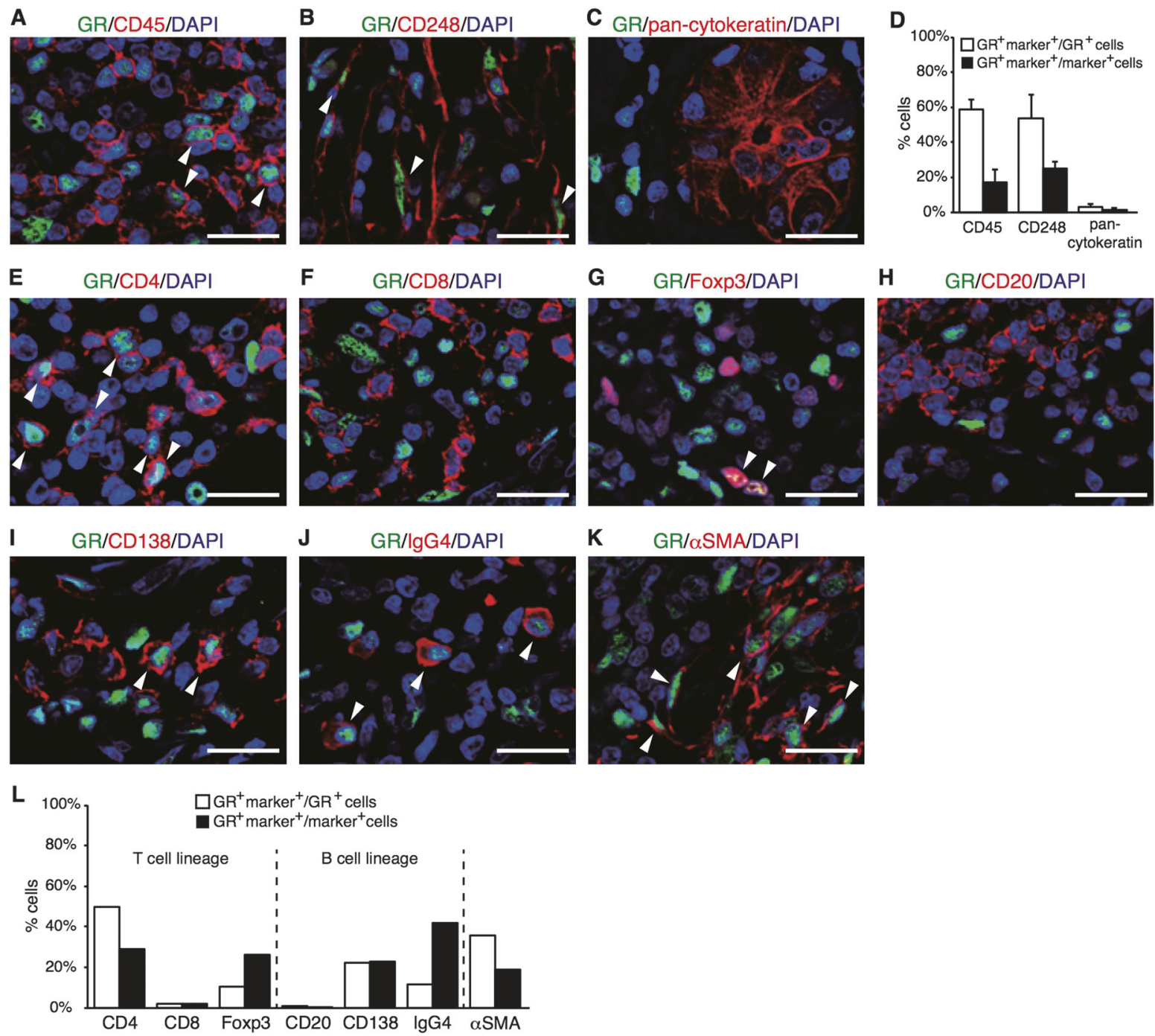

Fig. 4 Cell types expressing glucocorticoid receptor in the submandibular glands of IgG4-related disease patients. a-c Glucocorticoid receptor was expressed in $\mathrm{CD} 45^{+}$leukocytes $\mathbf{a}$ and fibroblasts $\mathbf{b}$, but not in epithelial cells c. d Quantification of glucocorticoid receptor expressions in four patients indicated that glucocorticoid receptor was abundantly expressed in both leukocytes and fibroblasts. e-l Glucocorticoid receptor was expressed in $\mathrm{CD} 4^{+} \mathrm{T}$ cells e, regulatory $\mathrm{T}$ cells $\mathbf{g}$, plasma sells $\mathbf{i}$, and $\mathrm{IgG}^{+}$cells $\mathbf{j}$, but not in $\mathrm{CD} 8^{+} \mathrm{T}$ cells $\mathbf{f}$ or B cells

h. Glucocorticoid receptor was also expressed in myofibroblasts k. $\mathbf{l}$ Quantification of cell types expressing glucocorticoid receptor in one patient indicated that glucocorticoid receptor was highly expressed in $\mathrm{CD}^{+}{ }^{+} \mathrm{T}$ cells, plasma cells, and myofibroblasts. Scale bars: $20 \mu \mathrm{m}$. Arrowheads indicate cells positive for both glucocorticoid receptor and cell markers. Abbreviations: IgG4-RD, IgG4-related disease; GR, glucocorticoid receptor 
Fig. 5 Cell types expressing glucocorticoid receptor in the kidney of IgG4-related disease patients. a, b Glucocorticoid receptor was expressed in CD45 ${ }^{+}$leukocytes a and fibroblasts $\mathbf{b}$. c Quantification of glucocorticoid receptor expressions in four patients indicated that glucocorticoid receptor was abundantly expressed in both leukocytes and fibroblasts. $\mathbf{d}-\mathbf{i}$

Glucocorticoid receptor was expressed in $\mathrm{CD}^{+}{ }^{+} \mathrm{T}$ cells $\mathbf{d}$, plasma cells $\mathbf{f}, \mathrm{IgG} 4^{+}$cells $\mathbf{g}$, but not in B cell e. Glucocorticoid receptor was also expressed in myofibroblasts $\mathbf{h}$. i

Quantification of cell types expressing glucocorticoid receptor in one patient indicated that glucocorticoid receptor was highly expressed in $\mathrm{CD}^{+}$

$\mathrm{T}$ cells, plasma cells, and myofibroblasts. Scale bars: 20 $\mu \mathrm{m}$. Arrowheads indicate cells positive for both glucocorticoid receptor and cell markers.

Abbreviations: IgG4-RD, IgG4-

related disease; GR,

glucocorticoid receptor
IgG4-RD (renal biopsy)
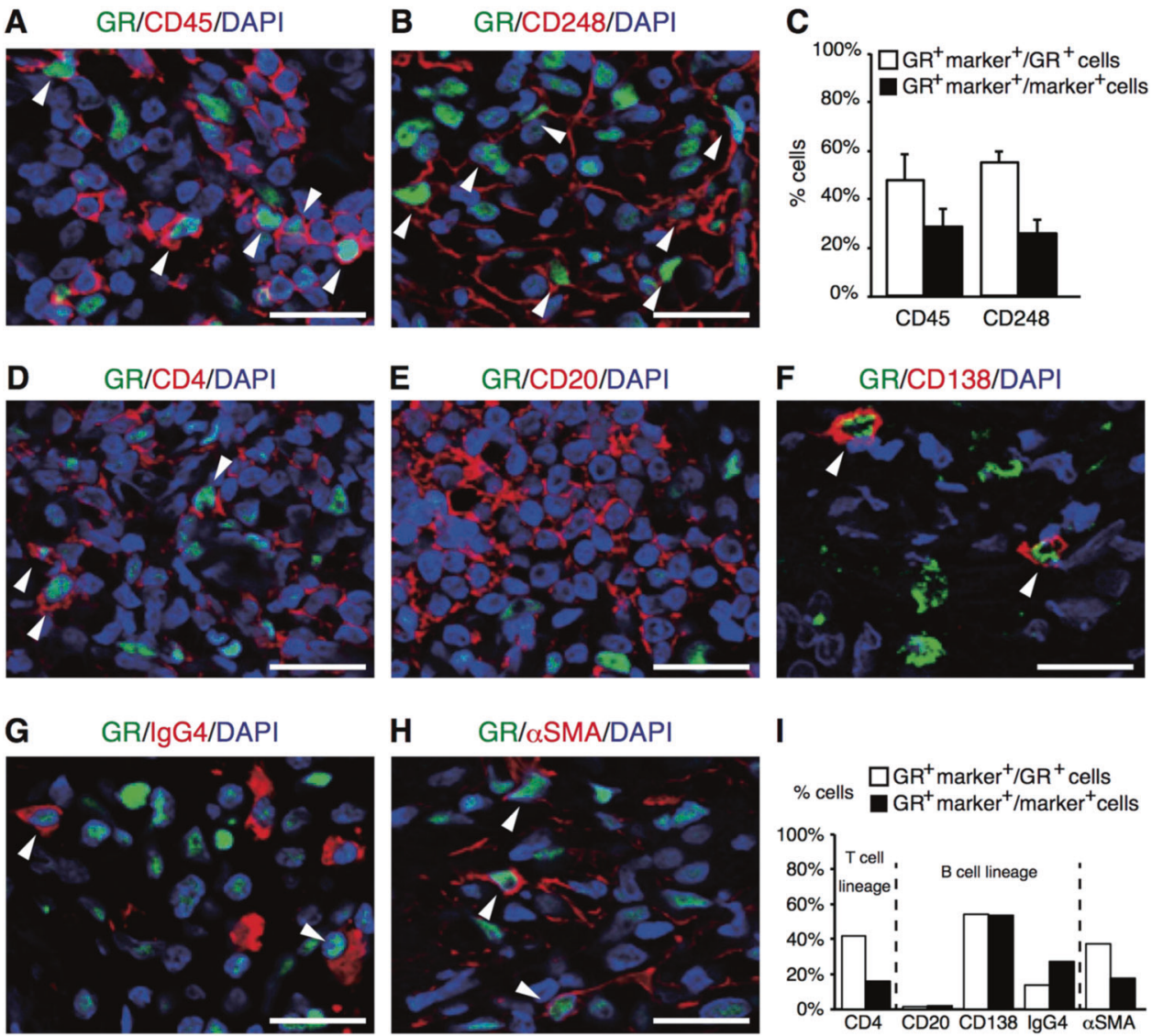

reduced erythropoietin-producing ability in myofibroblasts. Thus, fibro/myofibroblasts have the potential to change their phenotypes in response to glucocorticoids. These results indicate that glucocorticoid treatment for IgG4-related disease not only targets $\mathrm{T}$ cells and plasma cells but might also affect fibro/myofibroblasts directly.

We also analyzed whether glucocorticoid receptor expression correlates with the markers for IgG4-related disease, such as serum IgG4 concentration and IgG4/IgG ratio, but no significant correlation was observed (data not shown).

There are some limitations in this work. Because IgG4related disease is a rare disease, the number of patients analyzed in this study is limited. Furthermore, the specimens are small and the number of sections obtained from each case is also limited. Another limitation is the lack of comparison of glucocorticoid receptor expression before and after glucocorticoid treatment. Because most IgG4related disease patients respond well to the first round of glucocorticoid treatment, re-biopsy after treatment is unlikely.

Regardless of these limitations due to the rare nature of this disease, we have been able to show the abundant expression of glucocorticoid receptor in various tissues of
IgG4-related disease patients. In addition, glucocorticoid receptor expression was observed in both leukocytes and fibroblasts in IgG4-related disease patients, mostly in $\mathrm{CD}^{+}$ $\mathrm{T}$ cells, plasma cells, and fibro/myofibroblasts in IgG4related disease patients. The strong expression of glucocorticoid receptor in fibroblasts raises the possibility that glucocorticoids directly affect fibroblasts and attenuate fibrosis in IgG4-related disease.

Our results raise the possibility that glucocorticoids might target parenchymal cells in other inflammatory diseases as well. Further analysis of glucocorticoid receptor expression in affected tissues of other diseases might yield additional clues about the mechanism of action of glucocorticoids.

Acknowledgements We appreciate valuable discussion with Professor Jürgen Floege and Professor Pierre Ronco during the preparation of the manuscript. This study was performed as one of the collaborative projects of the IgG4-RKD Working Group within the Japanese Society of Nephrology. We thank Ms. Tomita and Ms. Ozone for their excellent technical assistance. This study was supported by the Funding Program for Next-Generation World-leading Researchers, "Project for Elucidating and Controlling Mechanisms of Aging and Longevity" from Japan Agency for Medical Research and development, AMED, Grant-in-Aids for Scientific Research B (26293202, 17H04187) from the Japan Society for the Promotion of Science 
(JSPS), CREST from the Japan Science and Technology Agency, and partly by grants from the TMK Project, Mitsubishi Tanabe Pharma Corporation.

\section{Compliance with Ethical Standards}

Conflict of interest T.I. is an employee of the Mitsubishi Tanabe Pharma Corporation. M.Y. is on the advisory board of Astellas and receives research grants from Astellas, Chugai, Daiichi Sankyo, Fujiyakuhin, Kyowa Hakko Kirin, Mitsubishi Tanabe Pharma Corporation, MSD, Nippon Boehringer Ingelheim, and Torii.

\section{References}

1. Stone JH, Zen Y, Deshpande V. IgG4-related disease. N Engl J Med. 2012;366:539-51.

2. Umehara H, Okazaki K, Masaki Y, et al. A novel clinical entity, IgG4-related disease (IgG4RD): general concept and details. Mod Rheumatol. 2012;22:1-14.

3. Mahajan VS, Mattoo H, Deshpande V, et al. IgG4-related disease. Annu Rev Pathol. 2014;9:315-47.

4. Saeki T, Nishi S, Imai N, et al. Clinicopathological characteristics of patients with IgG4-related tubulointerstitial nephritis. Kidney Int. 2010;78:1016-23.

5. Kawano M, Saeki T, Nakashima H, et al. Proposal for diagnostic criteria for IgG4-related kidney disease. Clin Exp Nephrol. 2011;15:615-26.

6. Saeki T, Kawano M, Mizushima I, et al. The clinical course of patients with IgG4-related kidney disease. Kidney Int. 2013;84:826-33.

7. Cortazar FB, Stone JH. IgG4-related disease and the kidney. Nat Rev Nephrol. 2015;11(10):599-609.

8. Alexander MP, Larsen CP, Gibson IW, et al. Membranous glomerulonephritis is a manifestation of IgG4-related disease. Kidney Int. 2013;83:455-62.

9. Rhen T, Cidlowski JA. Antiinflammatory action of glucocorticoids--new mechanisms for old drugs. $\mathrm{N}$ Engl $\mathrm{J}$ Med. 2005;353:1711-23.

10. Kamisawa T, Shimosegawa T, Okazaki K, et al. Standard steroid treatment for autoimmune pancreatitis. Gut. 2009;58:1504-7.

11. Kamisawa T, Okazaki K, Kawa S, et al. Japanese consensus guidelines for management of autoimmune pancreatitis: III. Treatment and prognosis of AIP. J Gastroenterol. 2010;45:471-7.

12. Khosroshahi A, Wallace ZS, Crowe JL, et al. International consensus guidance statement on the management and treatment of IgG4-related disease. Arthritis Rheumatol. 2015;67:1688-99.

13. Saeki T, Kawano M, Mizushima I, et al. Recovery of renal function after glucocorticoid therapy for $\mathrm{IgG} 4$-related kidney disease with renal dysfunction. Clin Exp Nephrol. 2016;20:87-93.
14. Bazso A, Szappanos A, Patocs A, et al. The importance of glucocorticoid receptors in systemic lupus erythaematosus. A systematic review. Autoimmun Rev. 2015;14:349-51.

15. van Everdingen AA, Huisman AM, Wenting MJ, et al. Down regulation of glucocorticoid receptors in early-diagnosed rheumatoid arthritis. Clin Exp Rheumatol. 2002;20:463-8.

16. Li X, Zhang FS, Zhang JH, et al. Negative relationship between expression of glucocorticoid receptor alpha and disease activity: glucocorticoid treatment of patients with systemic lupus erythematosus. J Rheumatol. 2010;37:316-21.

17. Gladman DD, Urowitz MB, Doris F, et al. Glucocorticoid receptors in systemic lupus erythematosus. J Rheumatol. 1991;18:681-4.

18. Umehara H, Okazaki K, Masaki Y, et al. Comprehensive diagnostic criteria for IgG4-related disease (IgG4-RD), 2011. Mod Rheumatol. 2012;22:21-30.

19. Sinicrope FA, Ruan SB, Cleary KR, et al. bcl-2 and p53 oncoprotein expression during colorectal tumorigenesis. Cancer Res. 1995;55:237-41.

20. Kuppe C, van Roeyen C, Leuchtle K, et al. Investigations of glucocorticoid action in GN. J Am Soc Nephrol. 2017;28:1408-20.

21. Tanaka H, Akama H, Ichikawa Y, et al. Glucocorticoid receptor in patients with lupus nephritis: relationship between receptor levels in mononuclear leukocytes and effect of glucocorticoid therapy. J Rheumatol. 1992;19:878-83.

22. Tanaka A, Moriyama M, Nakashima $\mathrm{H}$, et al. Th2 and regulatory immune reactions contribute to IgG4 production and the initiation of Mikulicz disease. Arthritis Rheum. 2012;64:254-63.

23. Zen Y, Fujii T, Harada K, et al. Th2 and regulatory immune reactions are increased in immunoglobin G4-related sclerosing pancreatitis and cholangitis. Hepatology. 2007;45:1538-46.

24. Nakashima H, Miyake K, Moriyama M, et al. An amplification of IL-10 and TGF-beta in patients with IgG4-related tubulointerstitial nephritis. Clin Nephrol. 2010;73:385-91.

25. Wynn TA. Fibrotic disease and the $\mathrm{T}(\mathrm{H}) 1 / \mathrm{T}(\mathrm{H}) 2$ paradigm. Nat Rev Immunol. 2004;4:583-94.

26. Maehara $\mathrm{T}$, Moriyama $\mathrm{M}$, Nakashima $\mathrm{H}$, et al. Interleukin-21 contributes to germinal centre formation and immunoglobulin G4 production in IgG4-related dacryoadenitis and sialoadenitis, so-called Mikulicz's disease. Ann Rheum Dis. 2012;71:2011-9.

27. Deshpande V, Zen Y, Chan JK, et al. Consensus statement on the pathology of IgG4-related disease. Mod Pathol. 2012;25:1181-92.

28. Asada N, Takase M, Nakamura J, et al. Dysfunction of fibroblasts of extrarenal origin underlies renal fibrosis and renal anemia in mice. J Clin Invest. 2011;121:3981-90.

29. Souma T, Yamazaki S, Moriguchi T, et al. Plasticity of renal erythropoietin-producing cells governs fibrosis. J Am Soc Nephrol. 2013;24:1599-616. 